\title{
CERVANTES Y CALDERÓN: EL GRAN TEATRO DEL MUNDO
}

No escasean en las comedias de Don Pedro Calderón las referencias al ingenioso hidalgo y a la caballería andante ${ }^{1}$. En Dicha y desdicha del nombre, la criada, aludiendo al amo del gracioso, le pregunta a éste: « ¿De dónde nos vino este / Don Quijote de la Mancha?» ${ }^{2}$. Roque, en Mañana será otro día, le recuerda a su señor que sus quijotadas han dado cuerda al enredo: «Pues si tengo de contarlo, / escucha desde el principio. / Después que de amparador / juraste ayer el oficio, / Don Quijote de prestado, / Don Esplandián de poquito" ${ }^{3}$. Cuando Calderón empieza a escribir, Don Quijote y Sancho ya son parte de la vida del pueblo, apareciendo sus figuras entre gigantes y cabezudos, en fiestas y procesiones.

La representación de Los disparates de don Quijote ${ }^{4}$ en el palacio del Buen Retiro con ocasión de los carnavales de 1637 es índice de la fama que había alcanzado el ingenioso caballero Don Quijote de la Mancha. De esta comedia, que no llegó a publicarse, existía un manuscrito en 1682 según Vera Tassis, amigo de Cal-

1 Véase el estudio de JOSÉ CARLOS DE TORRES, "Enquijotóse mi amo", o el tema del caballero idealista en las comedias de Calderón", Actas del tercer congreso internacional de la Asociación de Cervantistas. Universitat de les Illes Balears, 1998, pp. 619-629.

2 Pedro Calderón de la Barca, Obras completas. Prólogo y notas de Ángel Valbuena Briones. Madrid, 1991, t. I, Comedias, p. 1810.

3 Pedro Calderón de la BarCa, Obras completas, t. I, op. cit., p. 774.

4 El título Los disparates de Don Quijote aparece en una memoria del tesorero real don Jerónimo de Villanueva, donde éste hace cuentas de los pagos hechos a los representantes que interpretaron la comedia. N. D. SHERGOLD, A History of the Spanish Stage from Medieval Times until the end of the XVIIth Century. Oxford, 1967, pp. 288-89. 
derón y editor de sus obras. Cómo fue ese «Don Quixote de la Mancha» ${ }^{5}$ sigue siendo un enigma, aunque no es improbable que desplegase un estilo afín al de algunas obras de tema caballeresco y mitológico que Calderón escribió por aquellos años, tales como La puente de Mantible, Los tres mayores prodigios y El mayor encanto amor. La pérdida de Los disparates de Don Quijote obliga a imaginar los episodios que Calderón podría haber espigado y a conjeturar la unidad que les habría dado en una comedia de corte carnavalesco. Las aventuras de Don Quijote en el Palacio de los Duques convocarían el interés del dramaturgo en tanto la exuberante puesta en escena desarrollada por Cervantes era adaptable a los medios técnicos del teatro del Coliseo.

El modelo cervantino del lector enloquecido inspira Las jácaras, entremés que dramatiza la pasión de su protagonista por las vidas de hombres y mujeres libres y valientes que canta con desenfado, día y noche, habiéndose convertido en «infame coronista / de azotes y galeras, / de ladrones, de trongas y hechiceras» ${ }^{6}$. En esta deliciosa farsa, el «Vejete», con la ayuda de un grupo de actores, intenta curar a su hija haciendo que se le aparezcan en carne y hueso los personajes que glorifica. Sin embargo, la terapia fracasa, y Mari Zarpa, la enquijotada juglaresa, tras arrepentirse, vuelve a las andadas una vez que se le pasa el susto.

Los entremeses y las novelas ejemplares de Cervantes también captaron el interés del dramaturgo. La cueva de Salamanca inspiró El dragoncillo, brillante pieza corta del teatro cómico calderoniano. En El escondido y la tapada, el gracioso Mosquito recuerda a Carrizales, el protagonista de la novela ejemplar El celoso extremeño. El autor de El mayor monstruo, los celos y A secreto agravio, secreta venganza encontró en diversas obras de Cervantes magistrales retratos del personaje celoso, además de un fino análisis de la pasión de los celos. Entre estas obras se destacan la novela de $E l$ curioso impertinente, intercalada en la Primera parte de Don Quijote; la trágica historia de Claudia Jerónima (capítulo LX de la Segunda parte); el entremés El viejo celoso y ejemplares relatos como La señora Cornelia y el ya mencionado Celoso extremeño.

Para Calderón, el novelista por antonomasia fue Cervantes; así lo proclama un personaje de la comedia Los empeños de un acaso: "Quisiera una dama yo / extravagante, y sujeto / capaz de novela, porque / es mi amor tan novelero, / que me le escribió Cervan-

\footnotetext{
5 Título que da el mismo Calderón y también Vera Tassis. Ver el estudio de José CARlos DE TORRES, "Enquijotóse mi amo"...», op. cit., p. 621.

6 PEdRo CALderón DE la BARCA, Entremeses, jácaras y mojigangas. Edición, introducción y notas de EVANGELINA RODRÍGUEZ y ANTONIO TORDERA. Madrid, 1982, p. 91 .
} 
tes» ${ }^{7}$. En ésta y otras muchas comedias Calderón lleva el enredo al límite de lo inverosímil, arrojando a sus personajes a un laberinto que los obliga a reflexionar. El asombroso guión en el que se encuentran haciendo sus papeles les induce a comparar lo que les ocurre con los incidentes de una novela. Como ha señalado José Carlos de Torres, desde sus primeras comedias Calderón va «teniendo conciencia de pertenecer a una gran tradición literaria y dramática» ${ }^{8}$. En esa tradición se destaca la obra maestra de Cervantes vista por el autor de La vida es sueño.

Alonso Quijano, paradigma del personaje poseído por una idea dominante, enfrentado al mundo desde el a priori de la voluntad, no pasó desapercibido para Calderón, creador de figuras demoníacas incapaces de abrevar en lo real el insaciable deseo que las consume. Al contemplar por vez primera la grandiosa ciudad de Nínive, Semíramis asombra a los que la escuchan diciendo: «... me ha parecido poco. / Mas no me espanto porque / objeto es más anchuroso / el de la imaginación / que el objeto de los ojos» ${ }^{9}$. La proyección al infinito de éste y de otros personajes calderonianos está determinada por una voluntad de poder divorciada de toda moral. Tal es el caso del emperador Aureliano, cuya lucidez, nada reñida con la desmesurada ambición que lo espolea, le lleva a sentar un principio universal aplicable a todo déspota: "¿Que busco ejemplos más propios / Si es en su concepto Rey / Si piensa que es Rey un loco?» ${ }^{10}$. Don Quijote, nuevo mito de la naciente Modernidad y encarnación de una voluntad pura al servicio del bien y de la justicia, fascinó a Calderón, incansable analista en varios géneros dramáticos de las paradojas y contradicciones del «idealismo».

Desde su primera salida, Don Quijote se involucra en aventuras que él mismo genera. Presto a "representar», es decir, a pensar, interpretar y ejecutar; Don Quijote "representa» gigantes donde Sancho ve molinos, y a base de ese representar, que es un interpretar, arremete con la lanza baja contra las desaforadas criaturas de enormes brazos, representándose a sí mismo al poner por obra la intención que lo mueve. Tras armarse caballero y haber decidido «irse por todo el mundo con sus armas y caballo a buscar las aventuras», Alonso Quijano, lector empedernido de la infinita aventura caballeresca, hace ahora su composición de lugar frente a unos molinos de viento y no ante la letra impresa.

7 JosÉ CARLOS DE TORRES, “"Enquijotóse mi amo”, o el tema del caballero idealista en las comedias de Calderón", op. cit., p. 620.

$8 \mathrm{Ib}$.

9 La hija del aire, I. Obras completas. Prólogo y notas de Ángel Valbuena BRIONES. Madrid, 1991, t. II, Dramas, p. 739.

10 Obras completas, II, op. cit., p. 73. 
Don Quijote rechaza la forma de las cosas que se le ponen por delante porque si las distinguiese vería molinos antes que gigantes, ventas más bien que castillos, bacías en vez de yelmos ${ }^{11}$. La distancia entre el sujeto que percibe y el objeto percibido configura las apariencias en algunos encuentros como la gran polvareda tras la que Don Quijote "ve» dos ejércitos que se le transmutan como por ensalmo en rebaños. Con las personas, aunque las tenga delante de las narices, el caballero impone su concepto. Así, las mozas de partido son doncellas; el pícaro ventero, el castellano de la fortaleza; su vecino, Pedro Alonso, el marqués de Mantua; Haldudo el rico, verdugo del joven Andrés, un mal caballero, y Aldonza Lorenzo, Dulcinea. Las aventuras de la Primera parte surgen del choque de la intención del héroe con personas, cosas y acontecimientos de la realidad cotidiana. Don Quijote domina el argumento hasta el capítulo 26, donde cede el protagonismo a otros personajes y a otras historias. Entre los capítulos 27 y el 42 de la Primera parte, Don Quijote sólo lleva la voz cantante en la aventura de los cueros de vino, en el discurso de las armas y las letras y en alguna jugosa conversación con Sancho, haciendo acto de presencia de manera esporádica en la dilatada aventura de la princesa Micomicona, inventada por el cura e interpretada por Dorotea. Por primera vez los personajes se disfrazan, anticipando el encantamiento de Don Quijote en el capítulo 46, y el tono de la Segunda parte, dominada por una visión carnavalesca de la existencia.

Si en el Quijote de 1605 triunfan técnicas afines a la farsa, en el de 1615 el arte del entremés y de la mojiganga sustentan un tono meditativo que hace hincapié en el carácter transitorio e ilusorio de la existencia. Sobre el irreparable fluir del tiempo reflexiona Auristela con profundo sentimiento cristiano (capítulo X del libro IV del Persiles), dirigiéndose a Periandro: «Nuestras almas como tú bien sabes, y como aquí me han enseñado, siempre están en continuo movimiento, y no pueden parar sino en Dios como en su centro. En esta vida los deseos son infinitos, y unos se encadenan de otros y se eslabonan, y van formando una cadena que tal vez llega al cielo, $\mathrm{y}$ tal vez se sume en el infierno" ${ }^{12}$. En el Persiles, Periandro (Persiles)

11 A lo largo de su obra, Calderón desarrolla toda una sicología y metafísica de la percepción. En El príncipe constante, un personaje, al ver la flota enemiga en la lejanía, habla de la "perspectiva dudosa" en la que surgen los objetos, "porque la distancia siempre / monstruos imposibles forma». La descripción de la flota se constituye como una auténtica fenomenología de la ilusión, "así en países azules / hicieron luces y sombras, / confundiendo mar y cielo, / con las nubes y las ondas, / mil engaños a la vista; / pues ella en tanto curiosa, / sólo percibió los bultos / y no distinguió las formas». Obras completas, II, pp. 251-252.

12 Miguel De Cervantes, Los trabajos de Persiles y Sigismunda. Edición de Carlos Romero MuÑoz. Madrid, 1997, p. 704. 
y Auristela (Sigismunda), junto con los personajes que se les acompañan en peregrinación desde las salvajes tierras y helados mares del Septentrión hasta la Ciudad Eterna, suman una imagen de la vida humana como peregrinación. Si en el Persiles los acasos, lances y aventuras representan las peripecias de la existencia, con sus golpes de buena y mala fortuna, en Don Quijote el caballero en busca de aventuras se inscribe involuntariamente en un guión que también dramatiza las tribulaciones del homo viator en este valle de lágrimas.

En la primera aventura de la Segunda parte, Sancho, al verse en un apuro con su señor a quien ha venido mintiendo, transforma a las tres campesinas que se acercan por el camino del Toboso en Dulcinea y dos acompañantes. Por primera vez en la novela se invierten los papeles, viendo Don Quijote a tres labradoras montadas sobre borricos o borricas mientras su atrevido escudero agarra el cabestro del jumento de una de las aldeanas, dirigiéndose a ella como si fuese Dulcinea. El caballero entra al trapo poniéndose de rodillas aunque mirando con «ojos desencajados y vista turbada a la que Sancho llamaba reina y señora» ${ }^{13}$.

Cervantes quiso provocar en el lector un sentimiento análogo al que sobrecoge al ingenioso hidalgo, ese estado de extrema admiración que provoca una suspensión del juicio. Tales estados abundan en el teatro de Calderón, ejemplificados por las palabras de Segismundo al despertarse en Palacio, cuando exclama asombrado: « ¿Válgame el cielo! ¿Qué veo? / ¡Válgame el cielo ! ¿Qué miro? / Con poco espanto lo admiro, / con mucha duda lo creo» ${ }^{14}$. El asombro o la admiración es la pasión del alma que va a mantener en vilo a personajes y lectores del Quijote de 1615.

En este Quijote el autor hace que el héroe, ensombrecido por la duda y atenazado por el asombro, suspenda el juicio y hasta se plegue a la prudencia. Ya hay indicios de tal estancamiento en la aventura del cuerpo muerto (capítulo XIX de la Primera parte), cuando una noche cerrada Don Quijote y Sancho ven en la distancia «multitud de luces que no parecían sino estrellas que se movían". Las apariencias se ajustan a la aventura caballeresca, despertando la aprehensión que provoca el temor ante lo desconocido, de ahí que anote el narrador: «Pasmóse Sancho en viéndolas, y Don Quijote no las tuvo todas consigo; tiró el uno del cabestro a su asno, y el otro de las riendas a su rocino, y estuvieron quedos, mirando atentamente lo que podía ser aquello, y vieron que las lumbres se iban acercando a ellos, y mientras más se llegaban mayores pare-

13 El ingenioso hidalgo Don Quijote de la Mancha, II, op. cit., pp. 109-110.

14 La vida es sueño. Edición de Cirf́́aco MORÓN. Madrid, 1994, p. 129. 
cían; a cuya vista Sancho comenzó a temblar como un azogado, y los cabellos de la cabeza se le erizaron a Don Quijote» ${ }^{15}$.

Varado en la duda, y embotada la espuela de la intención, Don Quijote no puede transformar las cosas del mundo en objetos ideales, tal como acostumbra, molinos en gigantes, ovejas en ejércitos, mozas de partido en doncellas, etc. La aventura del cuerpo muerto se parece en esencia al traumático encuentro con la encantada Dulcinea; en ambos casos Don Quijote se vuelve de mármol, incapaz de desear; en el primero porque las apariencias coinciden con los preliminares de una posible aventura, $\mathrm{y}$ en el segundo porque la fea labradora no concuerda con la imagen que tiene Don Quijote de su señora. En ambas instancias conviene la exclamación del atónito Aureliano en La gran Cenobia, "O los ojos que mienten o el deseo» ${ }^{16}$, lapidaria frase que define el estado de ánimo que el autor se propuso crear en el Quijote de 1615.

La admiración, pasión eminentemente teatral a la vez que filosófica y poética, sustenta la tensión que Cervantes consigue mantener a lo largo de la segunda parte. Tras concluir el episodio del encantamiento de Dulcinea en el que Sancho, convertido por decisión propia en intérprete y director de escena, encierra a su señor en un papel definido por el sentido común, el novelista, con la metáfora del gran teatro del mundo en el cuerpo, redacta a continuación el episodio de la carreta de "Las Cortes de la Muerte». En esta aventura de cepa carnavalesca, Don Quijote y Sancho se encuentran con una carreta «cargada de los más diversos y extraños personajes y figuras que pudieron imaginarse». El carretero es un feo demonio y con él viene "la misma Muerte con rostro humano", y junto a ella «un ángel con unas grandes y pintadas alas»; a un lado, «un emperador con una corona, al parecer de oro en la cabeza», y a los pies de la Muerte, "el dios Cupido sin venda en los ojos, pero con su arco, carcaj y saetas», entre otras "personas de diferentes trajes y rostros».

Don Quijote, tras alborotarse al contemplar tan abigarrado grupo de figuras, se alegra creyendo haberse topado con alguna nueva y peligrosa aventura. Pero el chasco no tarda en llegar cuando el diablo carretero le explica que él y su gente son recitantes de la compañía de Angulo el Malo, que acaba de hacer esa misma mañana en un lugar cercano el auto de Las Cortes de la Muerte y que ahora va de camino para hacerlo esa tarde en otro lugar que por estar tan cerca y excusarse de tener que desvestirse van todos con los atuendos que corresponden a los papeles que representan. Don

15 El ingenioso hidalgo Don Quijote de la Mancha, I, op. cit., p. 229.

16 Obras completas, II, p. 71. 
Quijote, al descubrir que los de la carreta son cómicos de la legua, se entrega a la reflexión; "que así como vi este carro imaginé que alguna aventura se me ofrecía; y ahora digo es menester tocar las apariencias con la mano para dar lugar al desengaño» ${ }^{17}$.

La abortada aventura caballeresca da paso a un grotesco y ridículo acontecimiento gracias a la impertinencia de uno de la compañía vestido de «moharracho» que asusta a Rocinante golpeando el suelo con las vejigas que lleva atadas a un palo, haciéndolo volar por la campaña hasta tirar a Don Quijote al suelo. El moharracho, figura carnavalesca que responde según Covarrubias en 1611 al «momarrache o botarga que en tiempo de carnabal sale con mal talle y mala figura, haciendo ademanes de espantarse de los que topa, y otras de espantarlos» ${ }^{18}$, monta el burro de Sancho, mientras éste atiende a su señor, galopándolo e imitando la caída de Don Quijote. El caballero quiere vengar la afrenta, pero Sancho le aconseja que evite un escuadrón «donde está la Muerte y pelean en persona emperadores» ${ }^{19}$. Y es que el todavía extraño grupo de personajes espera al caballero al pie de la carreta armados con guijarros. Don Quijote opta por la prudencia, absteniéndose de combatir a la canalla, al oír que Sancho ha dicho que entre las figuras no hay ningún caballero andante, "porque no puedo ni debo sacar la espada, como otras veces muchas te he dicho, contra quien no fuere armado caballero» ${ }^{20}$.

El extraño encuentro con los histriones incita a Don Quijote y a Sancho a reflexionar sobre el sentido teatral de la existencia. El juego entre acción y contemplación anuda la relación entre amo y criado a lo largo de toda la novela, en la que aparece el término «aventura» en numerosas variantes y en variedad de significados. A la vez se hace presente la palabra experiencia, que viene a significar la agridulce sabiduría que deja la resaca de cada aventura. La dialéctica entre aventura y experiencia que alienta a lo largo de la gran novela diría algo a Calderón, en cuyo teatro se pone a prueba no sólo la voluntad de aventura y la proyección ideal de los personajes, sino también sus vivencias. Entre otras obras, La vida es sueño y En la vida todo es verdad y todo mentira, someten el concepto de experiencia a una demoledora crítica.

Tras la abortada aventura, Sancho opina que nunca los cetros y coronas de los emperadores farsantes fueron de oro puro, sino de

17 El ingenioso hidalgo Don Quijote de la Mancha, II, op. cit., p. 117.

18 Citado por RAMÓN MENÉndez PIDAL, Poesía juglaresca y juglares. Madrid, 1942, p. 46

${ }_{19}$ El ingenioso hidalgo Don Quijote de la Mancha, II, op. cit., p. 119.

20 El ingenioso hidalgo Don Quijote d la Mancha, II, op. cit., pp. 116-120. 
oropel y hojalata. Don Quijote, entusiasmado con el concepto, se permite una analogía entre vida y teatro que estriba en la siguiente comparación: que tras acabar la comedia y «desnudarse "los actores" de los vestidos della, quedan todos los recitantes iguales", algo que también ocurre en "la comedia y trato de este mundo, donde unos hacen los emperadores, otros los pontífices y, finalmente, todas cuantas figuras se pueden introducir en una comedia; pero, en llegando al fin, que es cuando se acaba la vida, a todos les quita la muerte las ropas que los diferenciaban, y quedan iguales en la sepultura». Sancho aplaude la «brava comparación», añadiendo «que no es tan nueva que no la haya oído muchas y diversas veces como aquella del juego de ajedrez que mientras dura el juego, cada pieza tiene su particular oficio; y en acabándose el juego todas se mezclan, juntan y barajan, y dan con ellas en una bolsa, que es como dar con la vida en la sepultura ${ }^{21}$.

La comparación entre vida y teatro, además de ser un tópico recurrido por los personajes, es una gigantesca metáfora que sustenta la creatividad del Don Quijote, especialmente de su segunda parte ${ }^{22}$. La gran novela de Cervantes tuvo un gran impacto sobre Calderón, capaz de entenderla como ningún otro escritor de su generación; el mismo Calderón que puso en boca del Rey en El gran teatro del mundo los versos: "Que ya acabó mi papel / me dice una triste voz, / que me ha dejado al oírla / sin discurso ni razón» ${ }^{23}$. El autor de la Vida es sueño y artífice de los versos "Sueña el Rey, que es Rey y vive / con este engaño mandando, / disponiendo y

21 El ingenioso hidalgo Don Quijote de la Mancha, II, op. cit., p. 121.

22 Cervantes, preocupado con la unidad de la fábula o argumento, ata los cabos en la Segunda parte valiéndose del «lugar», el palacio de los Duques y la Ínsula Barataria, donde transcurren los capítulos 30-59 y 69, para un total de 31 capítulos de los 74 que contiene la Segunda parte. En los primeros veintinueve capítulos, los primeros siete están dedicados a iniciar la tercera salida, los capítulos 8-10 introducen el tema de la teatralidad, la inversión de papeles y su manipulación con el encantamiento de Dulcinea, que será un hilo conductor a lo largo de la obra. El capítulo 11 hace explícito el tema del teatro del mundo con el episodio de la carreta de Las Cortes de la Muerte. Los capítulos 12-15 desarrollan el encuentro con el caballero del bosque o de los espejos, en la que Sansón Carrasco hace el papel del caballero de los Espejos y sale trasquilado. Los capítulos 22 y 23 tocan la cuestión de la vida es sueño y los capítulos 25-27 el episodio del retablo de Maese Pedro, que desarrolla la problemática de la ilusión enfrentando al protagonista a una representación teatral de la materia caballeresca. En este episodio Don Quijote se acomoda en la venta para ver la representación de una historia sacada de los romances españoles y las crónicas francesas, orquestada por Ginés de Pasamonte en el papel de Maese Pedro. Llega el momento en que Don Quijote, arrebatado por la emoción, cruza la línea a la vez imaginaria y real entre los espectadores y la representación, repartiendo mandobles a diestra y siniestra contra la morisma que persigue a Don Gaiferos y a Melisendra.

23 Obras completas, III, op. cit., p. 215. 
gobernando" ${ }^{24}$, es el dramaturgo que se inspira en el episodio cervantino de la carreta de las Cortes de la Muerte para escribir la mojiganga Las visiones de la muerte, pequeña obra maestra que trata de acontecimientos cotidianos, protagonizados por un caminante y un grupo de actores que van de un pueblo a otro a representar un auto sacramental.

El dramaturgo dota a lo asumido y familiar de un aura fantástica y surreal al hacer que los actores y actrices salgan algo magullados del carro que ha volcado en un lodazal, sorprendiendo con su insólita presencia a un caminante (sutil personificación del hombre viador) que se había dormido a la vera del camino y que despierta de una pesadilla que últimamente lo viene abrumando para enfrentarse a las alucinaciones producidas por lo evidente, actual y palpable. El caminante, que había apoyado la cabeza sobre una bota de vino mientras echaba una siesta, al despertarse y ver la figura de la Muerte (el actor que sale tambaleándose de la carreta volcada), se pregunta: «¿Qué bota es ésta?», responde sobrecogido: «La almohada / sobre que yo estoy durmiendo / todavía, pues estoy / viendo que la vida es sueño».

Calderón tuvo en la Segunda parte del Quijote un laboratorio de situaciones de gran prestancia dramática, que le llevaron a meditar sobre ciertas cuestiones que le ocuparon a lo largo de su vida, y que merecen enumerarse: a) la idea del teatro del mundo traducida a un argumento dramático y a su puesta en escena; $b$ ) «representación", en el doble sentido del término, como pensar y como ejecución de una intención; c) la diferencia entre intérprete y papel como esencia del personaje; d) la puesta en escena del deseo o de la voluntad en función de su representación; e) la voluntad de imponer una certidumbre inconcusa sobre las propias representaciones; f) el experimento o prueba como núcleo central a la obra; $g$ ) la cuestión de la verosimilitud.

Estos cinco temas ya están presentes en los predecesores de Calderón, en Lope y su escuela y en la obra de Tirso de Molina; sin embargo, el planteamiento cervantino en El ingenioso hidalgo se acerca en más profundidad a lo que llegó a ser la problemática calderoniana. Aunque Calderón admiró el arte entremesil del Cervantes dramaturgo, volcó su entusiasmo sobre el Cervantes novelista, al que recuerda en sus comedias. La escritura de la segunda parte de El ingenioso hidalgo impuso una segunda reflexión a Cervantes sobre la novela y sus personajes, lo que le supuso experimentar con dos cuestiones que le preocupaban, la unidad de la fábula o argumento y la mayor o menor verosimilitud de los acon-

24 Obras completas, II, op. cit., p. 221. 
tecimientos. En Los trabajos de Persiles y Sigismunda, obra escrita al compás de la redacción de la Segunda parte de Don Quijote, Cervantes se propuso escribir una épica en prosa, logrando "un cuerpo de fábula entero en todos sus miembros», algo que los libros de caballería «nunca hacen» según la preceptiva que elabora el Canónigo en el capítulo XLVII. de la Primera parte del Quijote ${ }^{25}$.

Cervantes también buscó esa unidad en la segunda parte de su obra maestra, donde puso a prueba el idealismo de Don Quijote en un contexto experimental acotado por un principio de verosimilitud sutilmente desarrollado. Calderón trató la materia épica y caballeresca en varias obras, bebiendo en el caso de Los hijos de la fortuna en Teágenes y Claricea, de la misma fuente que Cervantes en su Persiles y Sigismunda de la obra de Heliodoro, Teágenes y Cariclea. En la comedia fantástica de tema caballeresco Auristela y Lisidante, el criado Merlín, en el papel de preceptista, le sigue la pista al argumento buscando inverosimilitudes en las peripecias y falta de unidad en la acción, y así le dice a su amo que lo que éste le acaba de contar no lo van a creer los demás: «¿Qué importará que nosotros / lo digamos, si los otros / no lo quisieren creer» ${ }^{26}$.

En el Quijote de 1615, Cervantes hace que el caballero se enfrente con lectores del Quijote de 1605. En los personajes del Duque y la Duquesa, Cervantes retrató a dos lectores que se divierten a costa del héroe a quien reciben y agasajan en su castillo, pero que engañan y burlan, por medio de escenificaciones de historias caballerescas, con todos los medios que su gran hacienda les permite. El engaño no lo dispara el choque espontáneo con el mundo, sino que es producto de la manipulación de empresarios y directores que falsifican el mundo espiritual de Don Quijote reduciéndolo a meras apariencias. Éste se convierte en un personaje patético, ya que le quitan la posibilidad de responder al juego de circunstancias y azares que han provocado buena parte de las aventuras de la Primera parte. En el palacio de los Duques Don Quijote no «representa» porque la materia caballeresca se la «representan»y por lo tanto es incapaz de generar la aventura al no poder desearla.

Don Quijote, al convertirse en intérprete de un papel que no es de su hechura, va perdiendo la facultad que lo define, la voluntad. En la Segunda parte, Don Quijote se mueve en un mundo que parece coincidir con las caballerías que lleva en la cabeza y en el corazón. Sin embargo, es sólo un teatro de apariencias, imágenes que engañan al caballero. El asombro que provoca la suspensión del juicio en personajes y lectores corresponde a los juegos del autor

25 Obras completas, II, op. cit., p. 565.

26 Obras completas, II, p. 2011. 
con la credibilidad o la inverosimilitud de los acontecimientos. Conviene recordar que fue Calderón el dramaturgo que ideó la puesta en escena en palacio cuando Segismundo, tras ser drogado, se despierta en una estancia lujosa vestido de ricas galas, rodeado de criados y oyendo músicas que jamás ha escuchado. El director de escena no es otro que su propio padre, a quien desconoce, Basilio, Rey de Polonia, autor del guión en el que Segismundo se ve forzado a hacer un impremeditado papel, víctima de un diabólico experimento. Calderón debió entender mejor que nadie el teatro experimental de los Duques a expensas de Don Quijote.

Calderón también encontraría afinidades con el impulso poético de la prosa cervantina, por ejemplo con aquellas palabras de Don Quijote al volver en sí tras haber estado dentro de la cueva de Montesinos un buen rato suspendido de una soga: «Dios os lo perdone, amigos; que me habéis quitado de la más sabrosa y agradable vida y vista que ningún humano ha visto ni pasado. En efecto: ahora acabo de conocer que todos los contentos de esta vida pasan como sombra y sueño, o se marchitan como la flor del campo. ¡Oh desdichado Montesinos! ¡Oh mal ferido Durandarte! ¡Oh sin ventura Belerma! ¡Oh lloroso Guadiana! y vosotras sin dicha hijas de Ruidera, que mostráis en vuestras aguas las que lloraron vuestros hermosos ojos!» ${ }^{27}$.

\section{ANTONIO REgALADO}

27 El ingenioso hidalgo Don Quijote de la Mancha, II, op. cit., p. 210. 